\title{
Mechanical, Microstructural and Mineralogical Analyses of Porous Clay Pots Elaborated with Rice Husks
}

\author{
Yeri Dah-Traoré, Lamine Zerbo, Mohamed Seynou*, Raguilnaba Ouedraogo \\ Laboratory of Molecular and Materials Chemistry, Chemistry Department, University Ouaga 1 Professor Joseph KI-ZERBO, \\ Ouagadougou, Burkina Faso \\ Email: *seynou1mohamed@yahoo.fr
}

How to cite this paper: Dah-Traoré, Y., Zerbo, L., Seynou, M. and Ouedraogo, R. (2018) Mechanical, Microstructural and Mineralogical Analyses of Porous Clay Pots Elaborated with Rice Husks. Journal of Minerals and Materials Characterization and Engineering, 6, 257-270.

https://doi.org/10.4236/jmmce.2018.63019

Received: February 12, 2018

Accepted: April 6, 2018

Published: April 9, 2018

Copyright $\odot 2018$ by authors and Scientific Research Publishing Inc. This work is licensed under the Creative Commons Attribution International License (CC BY 4.0).

http://creativecommons.org/licenses/by/4.0/

\begin{abstract}
This paper deals with the elaboration of porous ceramic pots with raw clay materials and rice husks for water filtration. The basic raw clays have been mixed with rice husks at different ratio $10 \%$ and $15 \%$ weight (wt) and sintering at $1200^{\circ} \mathrm{C}, 1300^{\circ} \mathrm{C}$ and $1400^{\circ} \mathrm{C}$ for 30 minutes. The elaborated pots have been tested for their densification properties and filtration flow. The mineralogy and microstructure of pot have been also studied to explain the different results. The pot with $10 \%$ wt rice husks and sintering at $1300^{\circ} \mathrm{C}$ during 30 minutes presents a sufficient porosity and mechanical strength to be used for water filtration.
\end{abstract}

\section{Keywords}

Ceramic, Porous Materials, Raw Clay, Rice Husks

\section{Introduction}

The analysis of water sector in Burkina Faso shows that $11 \%$ of urban population and $33 \%$ of rural population have no access to drinking water [1]. The principal reasons are the pollution of great part of surface and underground water. The pollutants are principally chemical (sulfate, nitrate, metals), physical (alteration of limpidity), microbiological and organic. Their origins are natural and anthropic. Chemical pollutants are generally present in the rock in salt form and dissolve in the running water at concentration higher than the standards of World Health Organization. The mining boom in our country is another reason of water pollution. The water resources of mining areas are polluted with cyanide and metals like arsenic, mercury. In addition, with population growth, the 
waters of the big cities are rich in lead, cadmium mainly from batteries, drain oils, fuels and garbage [2]. Besides, agricultural inputs (fertilizers and pesticides) participate significantly in water pollution.

To meet this situation, many polluted water treatment methods have been developed. Reverse osmosis, membrane techniques or electro-dialysis, bridged clays, and porous ceramic, are some examples of water treatment techniques [3] [4] [5]. Ceramic materials were hugely proposed for filtering polluted water. Thus mullite microfilters were synthesized and tested with outstanding results. Microfilter specificity resides in both its high micro-porosity and its mechanical strength [6].

In this work, porous clay pots are synthesized using rice husks and raw clay materials from Burkina Faso. The first part of the work is devoted to the characterization of the basic and additive raw materials. The second part concerns the formulation of a pots and its mechanical, mineralogical, microstructural and chemical characterization.

\section{Materials and Techniques}

\subsection{Materials}

The used raw clay was deposit in Namassa village, around $100 \mathrm{~km}$ in the north of Ouagadougou. Its geographic coordinates are $1^{\circ} 48^{\prime}$ West and $13^{\circ} 05^{\prime}$ North. This raw clay was used as a basic material on the elaboration of porous ceramic pots. The additive substance used material was rice husks. It is a major byproduct of rice milling process of local field of rice. It was used to create the pores in the ceramic bodies during the sintering.

In the rest of the paper, the raw clay and rice husks were abbreviated respectively NAM (from the Namassa village) and RHS.

\subsection{Techniques}

\subsubsection{Characterization of Raw Materials}

Atterberg limits (liquid limit, plastic limit and plastic index) of the powder clay were carried out according to NF P 94-051 standard [7].

Chemical analysis was performed with X-ray fluorescence wavelength dispersive technique with a Bruker TIGER S8. The samples were melted at $1250^{\circ} \mathrm{C}$ with lithium tetraborate. Reference certificated materials were used for calibration.

Mineralogical composition was estimated by X-ray diffraction using a Bruker D5000 diffractometer operating at $40 \mathrm{kV}-40 \mathrm{~mA}$ and employing a graphite monochromatic $\mathrm{CuK} \alpha$ radiation. The mineralogical composition was refined with Fourier Transform Infrared (FTIR) spectroscopy using a PERKIN ELMER A 100 with $\mathrm{KBr}$ as matrix.

Differential thermal analysis (DTA) and thermogravimetry (TG) analysis was carried out using SETARAM instrument operating at $10^{\circ} \mathrm{C} / \mathrm{min}$ from 20 to $1100^{\circ} \mathrm{C}$. Calcined alumina was taken as a reference. 
Sintering behaviour of NAM was carried out with a dilatometer Setaram TMA-92 working with $5^{\circ} \mathrm{C} / \mathrm{min}$ as heating rate. The raw samples were pressed with a $20 \mathrm{kN}$ force to form cylinders with $1 \mathrm{~cm}$ as green height. The measures were done in atmospheric air from $20^{\circ} \mathrm{C}$ to $1100^{\circ} \mathrm{C}$.

\subsubsection{Elaboration of Clay Pots Specimen}

Successive steps were used for the elaboration of specimen. The first step was the preparation of paste. The two crude samples were grounded until particle size less than $800 \mu \mathrm{m}$ for NAM and less than $2 \mathrm{~mm}$ for RHS before their mixing. The different mixtures according to Table 1 were humidified and grounded during $15 \mathrm{~min}$. The second step was the formatting of specimen. The obtained paste from the first step was pressed with $15 \mathrm{MPa}$ using Magnolfi-Bigalli press. The used moulds were silt form according to Figure 1. Each specimen was made with $200 \mathrm{~g}$ of moistened powder. For the evaluation of flexural strength, parallelepiped forms were also done. The different specimens were dried at $105^{\circ} \mathrm{C}$ for 24 hours before firing up to $1200^{\circ} \mathrm{C}, 1300^{\circ} \mathrm{C}$ or $1400^{\circ} \mathrm{C}$ for $30 \mathrm{~min}$ in an NABERTHERM P330 electric furnace. The heating rate was $10^{\circ} \mathrm{C} / \mathrm{min}$.

\subsubsection{Densification Properties of Fired Specimen}

The fired pots were tested for unit weight $(U W)$, shrinkage $(S)$, water absorption $(W A)$, flexural strength $(\sigma)$ and filtration flow $(F)$.

Unit weight was determined according to Equation (1). It corresponds to the ratio between the mass $\left(m_{s}\right)$ and the volume $\left(V_{s}\right)$ of the fired pots.

Table 1. Composition of the different specimen of pots.

\begin{tabular}{cccc}
\hline & NAM [\%] & RHS [\%] & Water/material \\
\hline P0 & 100 & 0 & $0.5 / 1$ \\
P10 & 90 & 10 & $1 / 4$ \\
P15 & 85 & 15 & $1.25 / 4$ \\
\hline
\end{tabular}

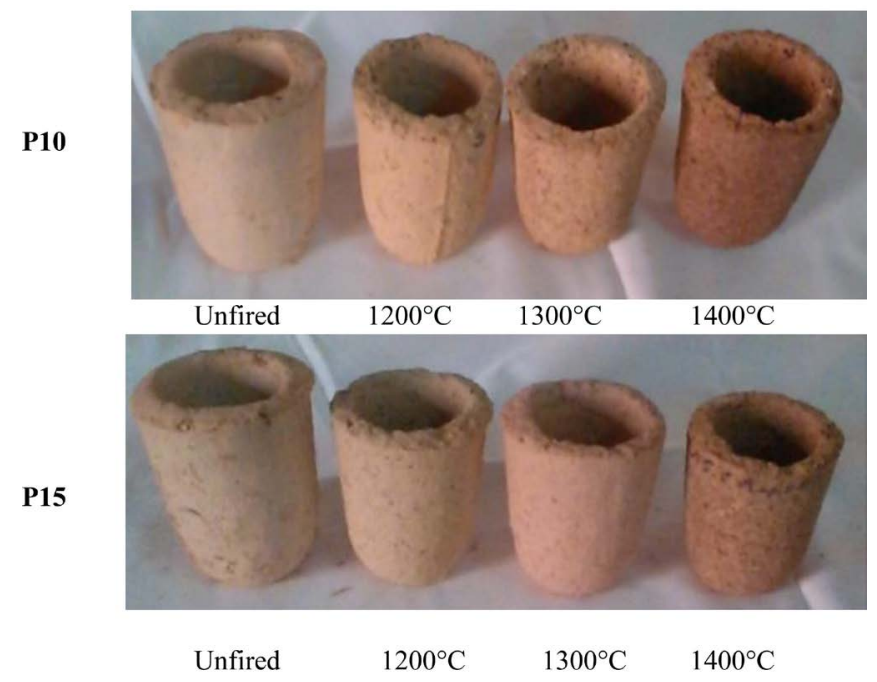

Figure 1. Specimens according to sintering temperature and the amount of RHS. 


$$
U W\left(\mathrm{~g} / \mathrm{cm}^{3}\right)=\frac{m_{s}}{V_{s}}
$$

The shrinkage was determined by means of the Equation (2) with $L_{s}$ and $L_{c}$ respectively the height of green and fired specimens.

$$
S(\%)=\frac{L_{s}-L_{c}}{L_{s}} \times 100
$$

The water absorption is the relation of the mass of absorbed water to the mass of the fired pots. It is calculated with the Equation (3) with $m_{s}$ and $m_{h}$ respectively the mass of fired pots and the mass of fired pots after two (2) hours in boiling water [8].

$$
W A(\%)=\frac{m_{h}-m_{s}}{m_{s}} \times 100
$$

The mechanical properties of specimens were measured by three points bending device with NANNETTI apparatus. The flexural strength $\sigma$ was evaluated by the Equation (4) [9].

$$
\sigma=\frac{3 F E}{2 l e^{2}}
$$

where: $F$-applied force, $E$-distance between the two supports, $I$-the width of the bar, and $e$-its thickness.

The flow $(F)$ of each fired pot was determined (Equation (5)). The same quantity of distilled water $(V)$ was put on each specimen and the necessary time $(t)$ for its filtration was determined. The test is repeated four times for each pot. After each test, the pot is rinsed and dried at $105^{\circ} \mathrm{C}$ before the second test.

$$
F\left(\mathrm{~cm}^{3} / \mathrm{s}\right)=\frac{V}{t}
$$

\subsubsection{Microstructural Characterization of Fired Pots}

Mineralogical evolution of fired pots was assessed using X-ray diffraction of the fired pot powder $(<80 \mu \mathrm{m})$.

Microstructural evolution of fired pots was observed with scanning electron microscopy with apparatus type LEO $450 \mathrm{VP}$. A semi-quantitative chemical analysis using X-ray Energy Dispersive Spectrometer (EDS) was performed to complete the mineralogical characterization.

\section{Results and Discussion}

\subsection{Characterization of Raw Materials}

\subsubsection{Raw Clay Material (NAM)}

Atterberg limits of NAM are presented on the Table 2. According to Casagrande diagram [10], Atterberg limits show that NAM is a clay with plasticity. The liquid limit of material permits to show the passage to liquid stage to plastic stage. This plasticity is interesting for the typesetting of the specimen. The feeble specific area shows that the sample must contain a clay without an interlayer. Table 3 presents the elementary chemical analysis of NAM. The main oxides are $\mathrm{SiO}_{2}$ 
and $\mathrm{Al}_{2} \mathrm{O}_{3}$ and indicate that NAM is consisting principally by clay phases. The iron oxide $\mathrm{Fe}_{2} \mathrm{O}_{3}$ and potassium oxide $\mathrm{K}_{2} \mathrm{O}$ are in relatively high quantity. $\mathrm{Fe}_{2} \mathrm{O}_{3}$ is ascribable to goethite and $\mathrm{K}_{2} \mathrm{O}$ shows the presence of illite or muscovite phase in NAM. The loss on ignition $(9.88 \% \mathrm{wt})$ is high and corroborates the predominance of clay phase in NAM. The analysis of X-ray diffraction pattern (Figure 2) according to ASTM (American Standards for Testing Materials) on open data base indicated that kaolinite, illite, montmorillonite, goethite and quartz are the main phases which compose NAM. Infrared spectra (Figure 3) corroborated the $\mathrm{X}$-ray diffraction results. The characteristics covalent bonding and functional groups of kaolinite, illite, montmorillonite and quartz are presented on the infrared spectra. The band around $3600 \mathrm{~cm}^{-1}$ is attributable to the bond $\mathrm{Al}-\mathrm{OH}$ of kaolinite, and the band at $3620 \mathrm{~cm}^{-1}$ is the bond Al-OH of illite and montmorillonite. The double band at $797-778 \mathrm{~cm}^{-1}$ is ascribable to the bond $\mathrm{Si}-\mathrm{O}$ of

Table 2. Some geotechnical parameters of NAM raw clay.

\begin{tabular}{ccccc}
\hline Liquid limit [\%] & Plasticity limit [\%] & Plasticity index [\%] & $\begin{array}{c}\text { Density } \\
{\left[\mathrm{g} \cdot \mathrm{cm}^{-3}\right]}\end{array}$ & $\begin{array}{c}\text { Specific area } \\
{\left[\mathrm{m}^{2} \cdot \mathrm{g}^{-1}\right]}\end{array}$ \\
\hline 41.0 & 21.0 & 20.0 & 2.68 & 8.45 \\
\hline
\end{tabular}

Table 3. Chemical composition of NAM raw clay.

\begin{tabular}{ccccccccccc}
\hline Oxides & $\mathrm{SiO}_{2}$ & $\mathrm{Al}_{2} \mathrm{O}_{3}$ & $\mathrm{Fe}_{2} \mathrm{O}_{3}$ & $\mathrm{MgO}$ & $\mathrm{CaO}$ & $\mathrm{Na}_{2} \mathrm{O}$ & $\mathrm{K}_{2} \mathrm{O}$ & $\mathrm{TiO}_{2}$ & LOI & Total \\
\hline$[\%]$ & 53.74 & 28.23 & 4.61 & 0.64 & 0.11 & 0.08 & 2.37 & 0.42 & 9.88 & 100.08
\end{tabular}

LOI: Loss On Ignition at $1000^{\circ} \mathrm{C}$.

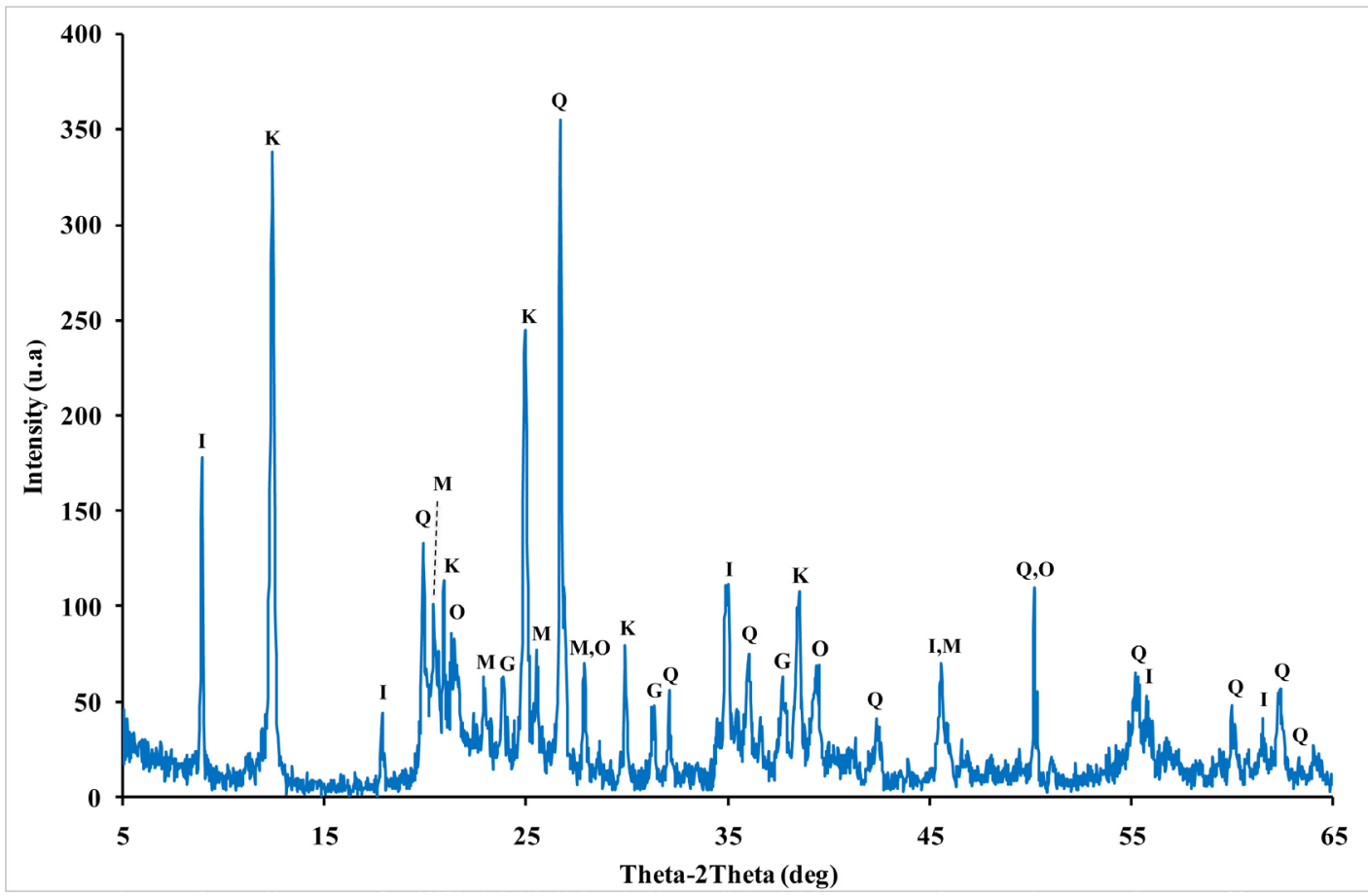

Figure 2. X-ray diffraction pattern of NAM raw clay. K: kaolinite, I: illite, M: montmorillonite, O: orthose, G: goethite, Q: quartz. 


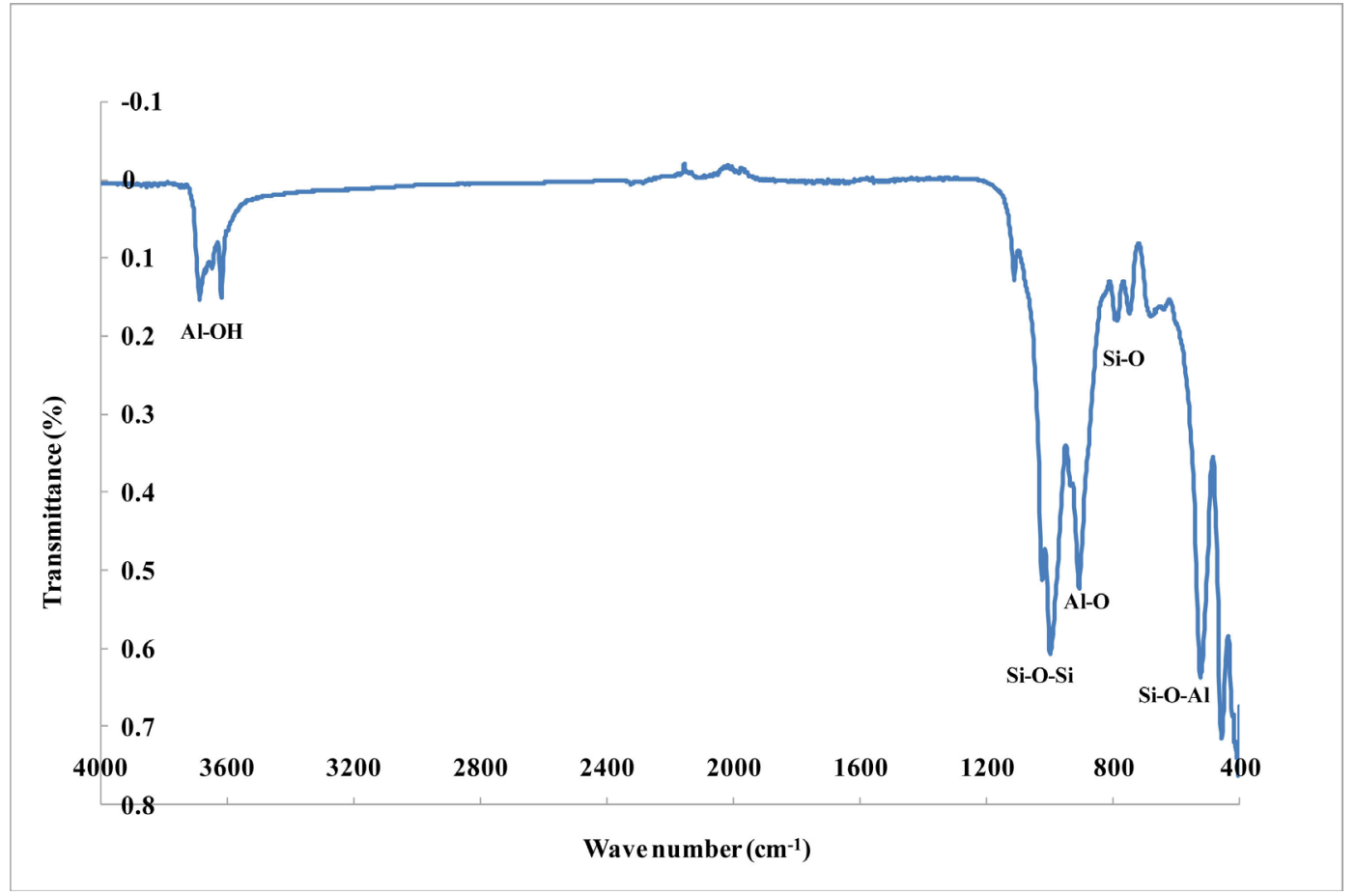

Figure 3. Infrared spectrum of NAM raw clay.

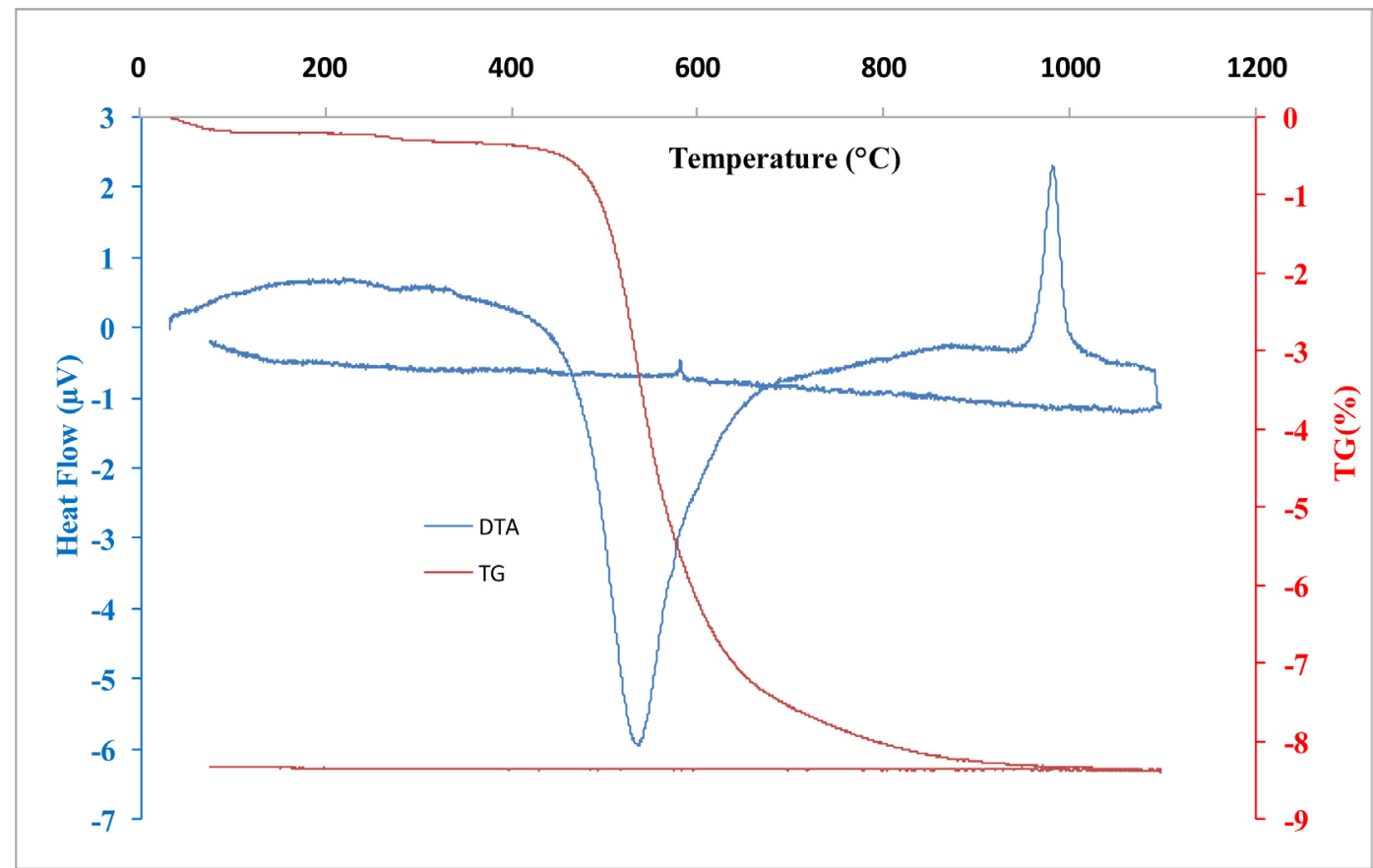

Figure 4. DTA and TG analysis of NAM raw clay.

quartz. The band around $913 \mathrm{~cm}^{-1}$ is typical for kaolinite bond Al-O [11]. DTA/TG results are shown by the Figure 4 . The results showed principally two peaks. The first, an endothermic peak between $400^{\circ} \mathrm{C}$ and $690^{\circ} \mathrm{C}$ corresponds to dehydroxylation of clays phases like kaolinite and illite. The last, an exothermic peak between $940^{\circ} \mathrm{C}$ and $1050^{\circ} \mathrm{C}$ corresponds to the structural reorganization of 
metakaolinite. To these important peaks is added a small endothermic peak between $250^{\circ} \mathrm{C}$ and $330^{\circ} \mathrm{C}$ and corresponds to goethite dehydroxylation into hematite. During the drop of temperature, the presence of quartz is clearly shown by the small exothermic peak at $574^{\circ} \mathrm{C}$ corresponds to the allotropic transformation of quartz $\beta$ to quartz $\alpha$ [12]. The different results of thermal analysis are agreed with those of $\mathrm{X}$-ray and infrared results.

By coupling chemical and mineralogical analysis, and using the formula proposed by Yvon et al. [13], a phasis semi-quantitative estimation has done. The Table 4 shows result of this semi-quantitative estimation of the different phase. The results indicate the predominance of kaolinite ( $42 \% \mathrm{wt}$ ) followed by illite (21\% wt), quartz (15\% wt), montmorillonite (13\%wt). Orthose ( $7 \% \mathrm{wt})$ and goethite $(5 \% \mathrm{wt})$ are in relative in high quantity. NAM mineralogical composition is very interesting for ceramic elaboration. It is composed by plastic phases (kaolinite, illite), non plastic phase (quartz) and fluxing phases (orthose, goethite). Kaolinite and illite are the sources of possible formation of mullite during the sintering and this mullite improves the ceramic mechanical properties. Quartz can contribute to the mechanical strength of the unfired specimen and participate with the fluxing phase to the formation of liquid phase which promotes the mechanical performances. Nevertheless, the presence of montmorillonite can be detrimental for the ceramic [12].

The sintering behavior of NAM is given by the Figure 5. The dilatometry curve presents some shrinkage characteristics of kaolinite successive thermal

Table 4. Semi-quantitative estimation of phases.

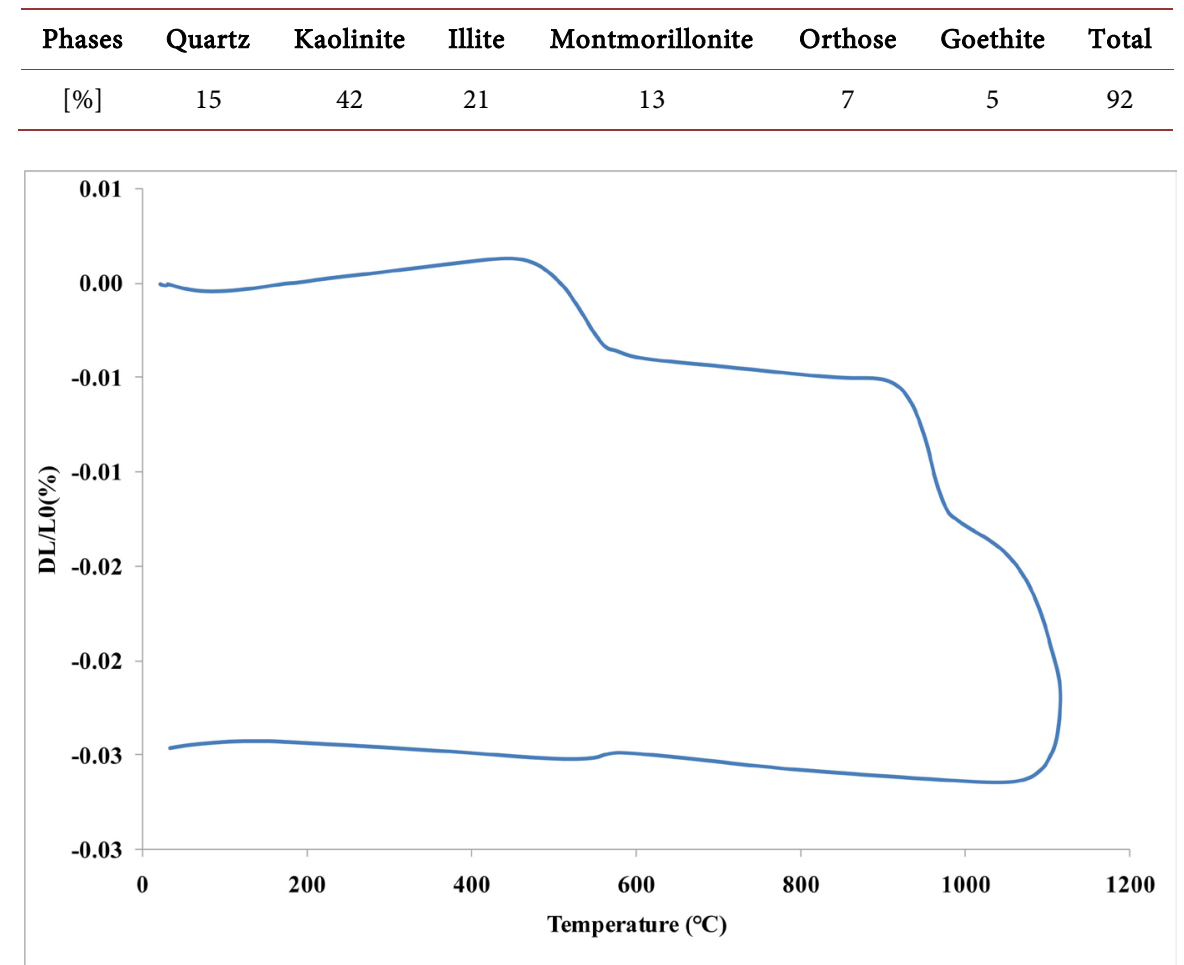

Figure 5. Dilatometric curve of NAM raw clay. 
transformation as shows the DTA curve. At these shrinkages we can notice that the densification of NAM during its sintering occurs around $1000^{\circ} \mathrm{C}$. Thus for the sintering of pots to obtain a better densification, the sintering temperature has been chosen higher than $1000^{\circ} \mathrm{C}$.

\subsubsection{Rice Husks (RHS)}

The ash quantity from rice husk sintering at $1000^{\circ} \mathrm{C}$ corresponds to $14 \% \mathrm{wt}$. The rice husks are composed essentially by organic matters which vanish during the sintering [14]. The released volume by the burn of organic matter is used to create the different pores on the ceramic during its sintering. The main oxide (Table 5) which composes the ashes is $\mathrm{SiO}_{2}$.

\subsection{Mechanical Properties of Fired Pots}

The evaluated properties of fired pots are shrinkage, unit weight loss, water absorption and compressive strength. For each property, several tests are making and the final result is the average.

Figure 6(a) shows the variation of shrinkage according to temperature and rice husk ratio. The shrinkage increases with increasing of temperature. The used of RHS increases significantly the shrinkage. The unit weight (Figure 6(b)) increases with temperature as the shrinkage but the ad of RHS decreases its values. During the sintering, the phases like kaolinite, illite and quartz are transformed by fluxing action into liquid phase and mullite. The quantity of formed phases increases with temperature and gives the densification of the pots which is responsible of the increase of shrinkage. With temperature the added RHS are burnt and vanished on the pots structure and increase then the shrinkage. However, an increasing of RHS ratio at 15\% wt shows shrinkage lower than the pots with $10 \%$ wt. With $15 \%$ wt RHS, the totally RHS are not vanished on the pots at the different temperatures and caused then the small reduction of shrinkage. The different reactions and phenomena affect the unit weight. The densification by the formation of liquid phase increases the unit weight. The use of RHS decreases the unit weight of pots because of the feeble unit weight of RHS. The different unit weight are agreed with those $\left(1.4-1.8 \mathrm{~g} \cdot \mathrm{cm}^{-3}\right)$ found by Görhan et al. [14].

The water absorption (Figure 6(c)) corroborates the unit weight and shrinkage. For each pot, water absorption decreases with temperature increasing. For each temperature, water absorption increases with increasing of RHS ratio. The water absorption is directly linked to porosity. With increasing temperature, the liquid phase increases and the pores are closed. The closing of pores reduces the water absorption. With RHS, the effect of liquid phase is reduced by the burn of RHS which release the carbon dioxide causing the formation of new pores.

Table 5. Chemical composition of rice husk.

\begin{tabular}{cccccccccc}
\hline Oxides & $\mathrm{SiO}_{2}$ & $\mathrm{Al}_{2} \mathrm{O}_{3}$ & $\mathrm{Fe}_{2} \mathrm{O}_{3}$ & $\mathrm{TiO}_{2}$ & $\mathrm{Na}_{2} \mathrm{O}$ & $\mathrm{MgO}$ & $\mathrm{K}_{2} \mathrm{O}$ & $\mathrm{CaO}$ & Total \\
\hline$[\%]$ & 96.84 & 1.03 & 0.38 & 0.1 & 0.03 & 0.32 & 0.81 & 0.47 & 99.98 \\
\hline
\end{tabular}




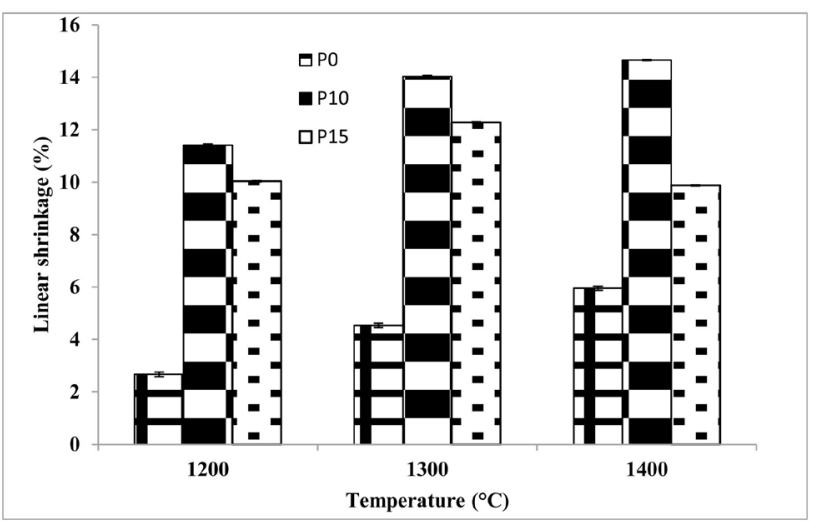

(a)

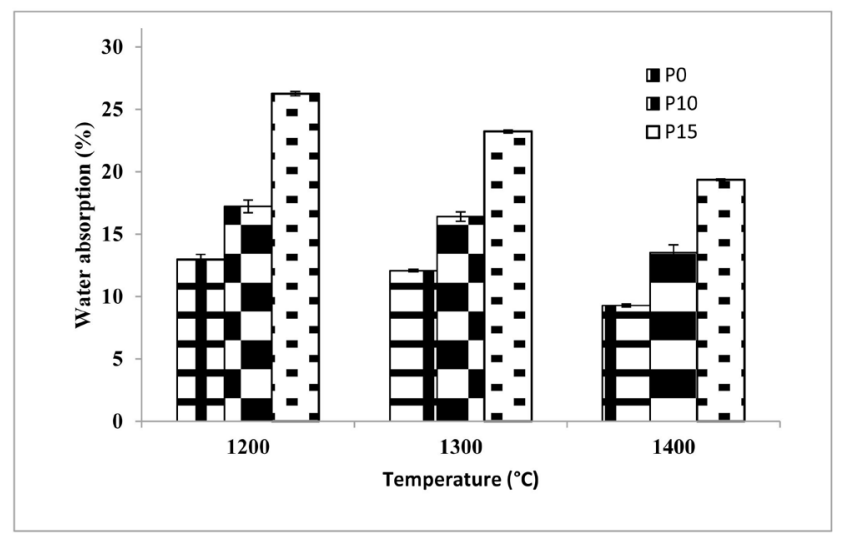

(c)

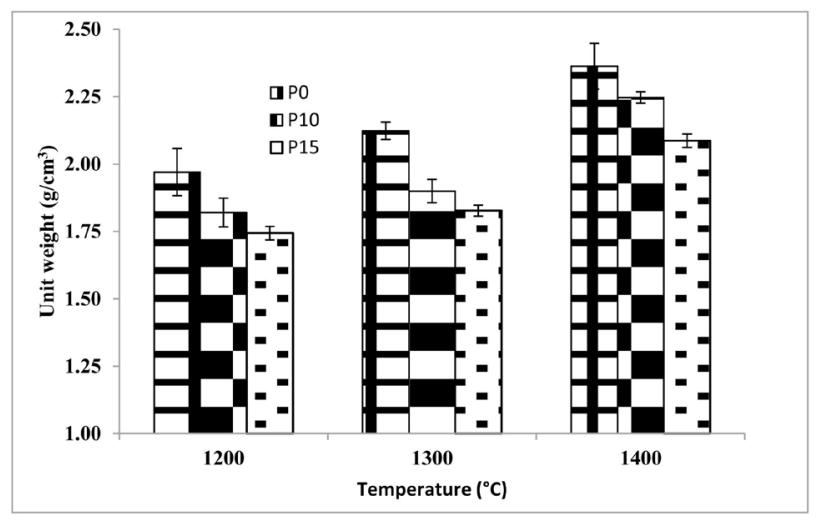

(b)

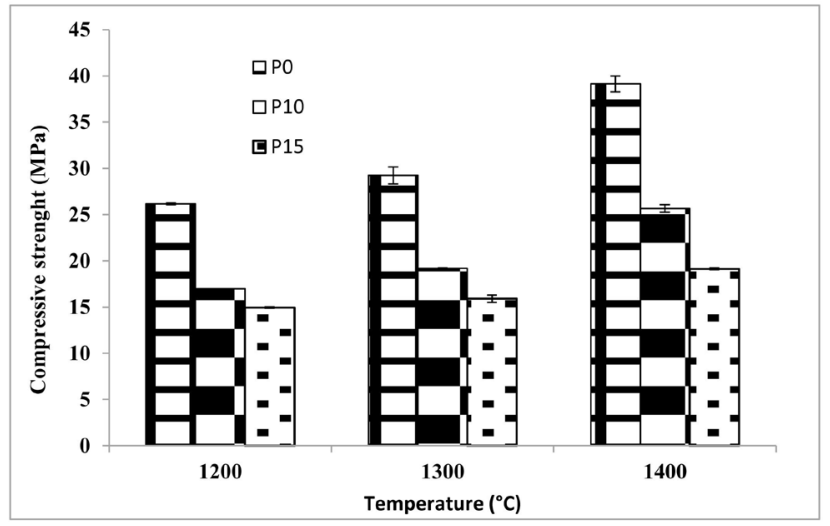

(d)

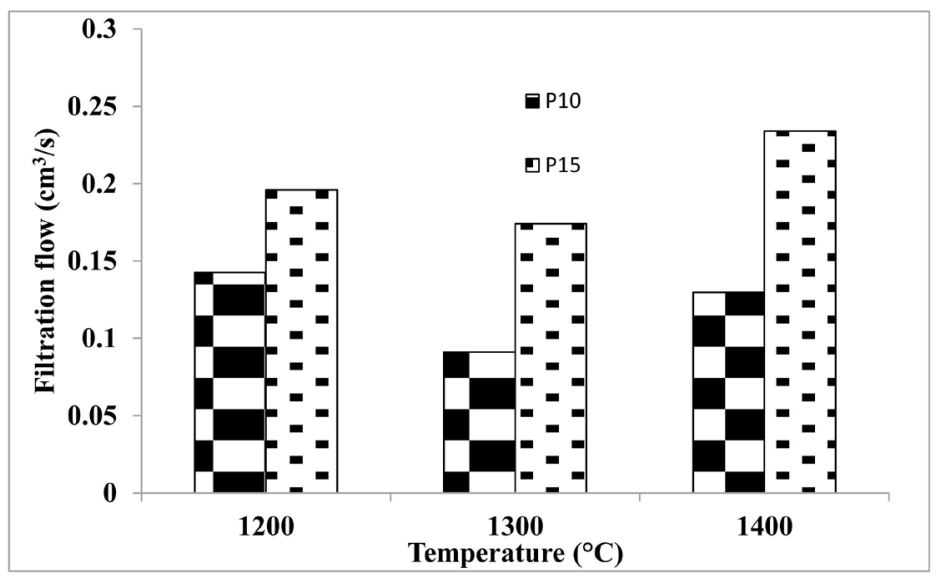

(e)

Figure 6. Mechanical properties of fired pots: (a) Linear shrinkage; (b) Unit weight; (c) Water absorption; (d) Compressive strength; (e) Filtration flow.

The compressive strength of pots is given by the Figure 6(d). Its values increase with temperature but decrease with the ad of rice husk. The compressive strength is the result of microstructure and mineralogy evolution of specimen. With closing of porosity by the liquid phase and the presence of mullite on the fired pots, the strength increases greatly. The difference between the pots without rice husks and the others is high due to the existence of porosity in great 
quantity on the pots made with rice husks. However, at $1300^{\circ} \mathrm{C}$ the flexural strength of materials $\mathrm{P} 10$ is around $20 \mathrm{MPa}$ which is close to the resistance of earthenware [15]. At $1400^{\circ} \mathrm{C}$ for the same materials $\mathrm{P} 10$, the flexural strength is around $25 \mathrm{MPa}$ like the flexural of fired bricks.

Figure 6(e) shows the filtration flow of specimen. The filtration flow increases with the quantity of rice husks. For all the specimens, the filtration flow decreases from $1200^{\circ} \mathrm{C}$ to $1300^{\circ} \mathrm{C}$ and increases after $1300^{\circ} \mathrm{C}$. The variation follows the porosity of the specimen. With $10 \%$ of RHS, the ceramic presents a better densification than that with $15 \%$ of RHS. This densification induced the reduction of porosity which reduces the filtration flow.

\subsection{Mineralogical Properties of Fired Pots}

The X-ray patterns of the sintering pots $\mathrm{P} 10$ are presented by the Figure 7 . The sintering pots are composed principally by mullite, cristobalite and quartz. The mullite provides on the transformation of kaolinite and illite during the sintering. The cristobalite is the result of quartz transformation. One part of quartz is transformed to cristobalite, the second part is dissolved by the fluxing phase action to form the liquid phase. The rest of quartz remains on the ceramic bodies. Increasing the sintering temperature, the mullite quantity increases. The cristobalite quantity also increases contrary to quartz which decreases. The evolution of pots mineralogy explains the different mechanical properties.

\subsection{Microstructural Evolution of Fired Pots}

Figure 8 gives the scanning image of surface rupture of $\mathrm{P} 0$ at different temperatures. At $1200^{\circ} \mathrm{C}$, the surface is characterized by very porous materials. At this temperature the densification of the pots is feeble and did not permit the close of

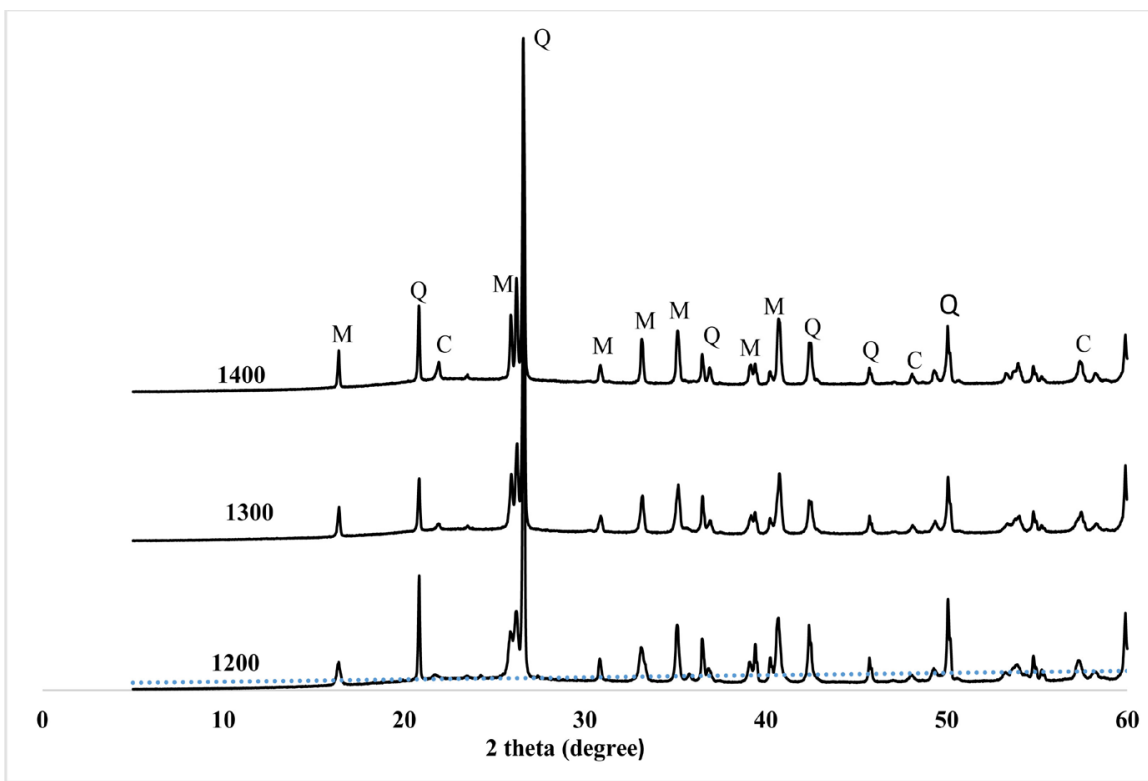

Figure 7. X-ray diffraction of P10 at different temperatures. M: mullite, Q: quartz, C: cristobalite. 

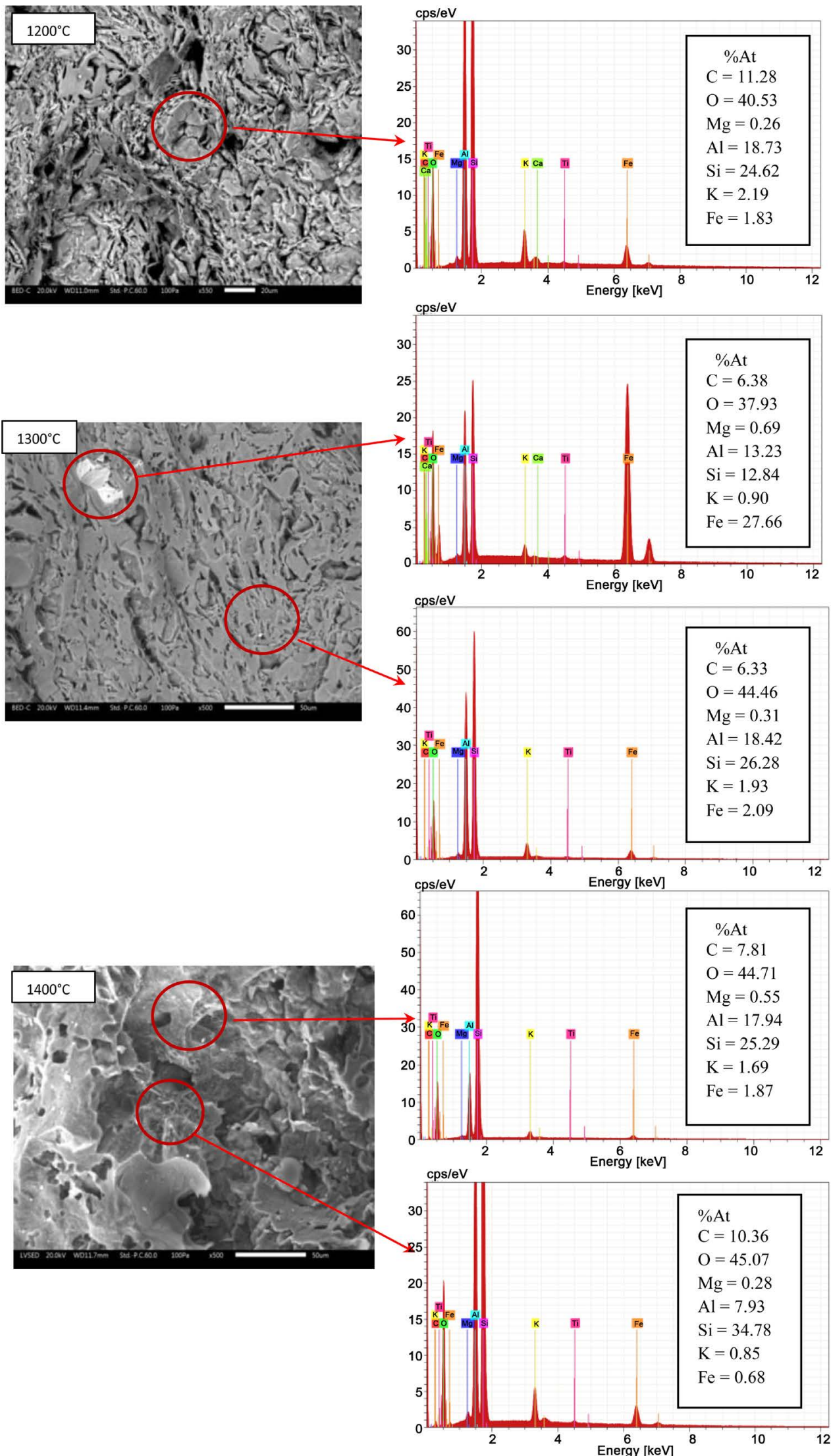

Figure 8. SEM image of fractured surface of $\mathrm{P} 0$ at $1200^{\circ} \mathrm{C}, 1300^{\circ} \mathrm{C}$ and $1400^{\circ} \mathrm{C}$. 
the pores. With the increase of sintering temperature at $1300^{\circ} \mathrm{C}$, the microstructure of surface rupture shows a densification of the pots with some microporosities. At $1400^{\circ} \mathrm{C}$, the microstructure shows an important quantity of liquid and mullite phase which reduce the porosity and improves the mechanical properties of fired pots with temperature. The chemical evolution of P0 with temperature shows a decrease of $\mathrm{K}_{2} \mathrm{O}$ and $\mathrm{Al}_{2} \mathrm{O}_{3}$ and the increase of $\mathrm{SiO}_{2}$. The different evolutions indicate the formation of mullite and liquid phase by the action of flux element $\left(\mathrm{K}_{2} \mathrm{O}\right)$ on kaolinite and quartz to produce mullite with free silica.

Figure 9 presents the scanning image of surface rupture of P10 and P15 at $1300^{\circ} \mathrm{C}$. P10 microstructure is similar to P0 at the same temperature but with great number of connected pores. The densification is observed but the pores come from the burn of RHS which release $\mathrm{CO}_{2}$. The image of P15 shows
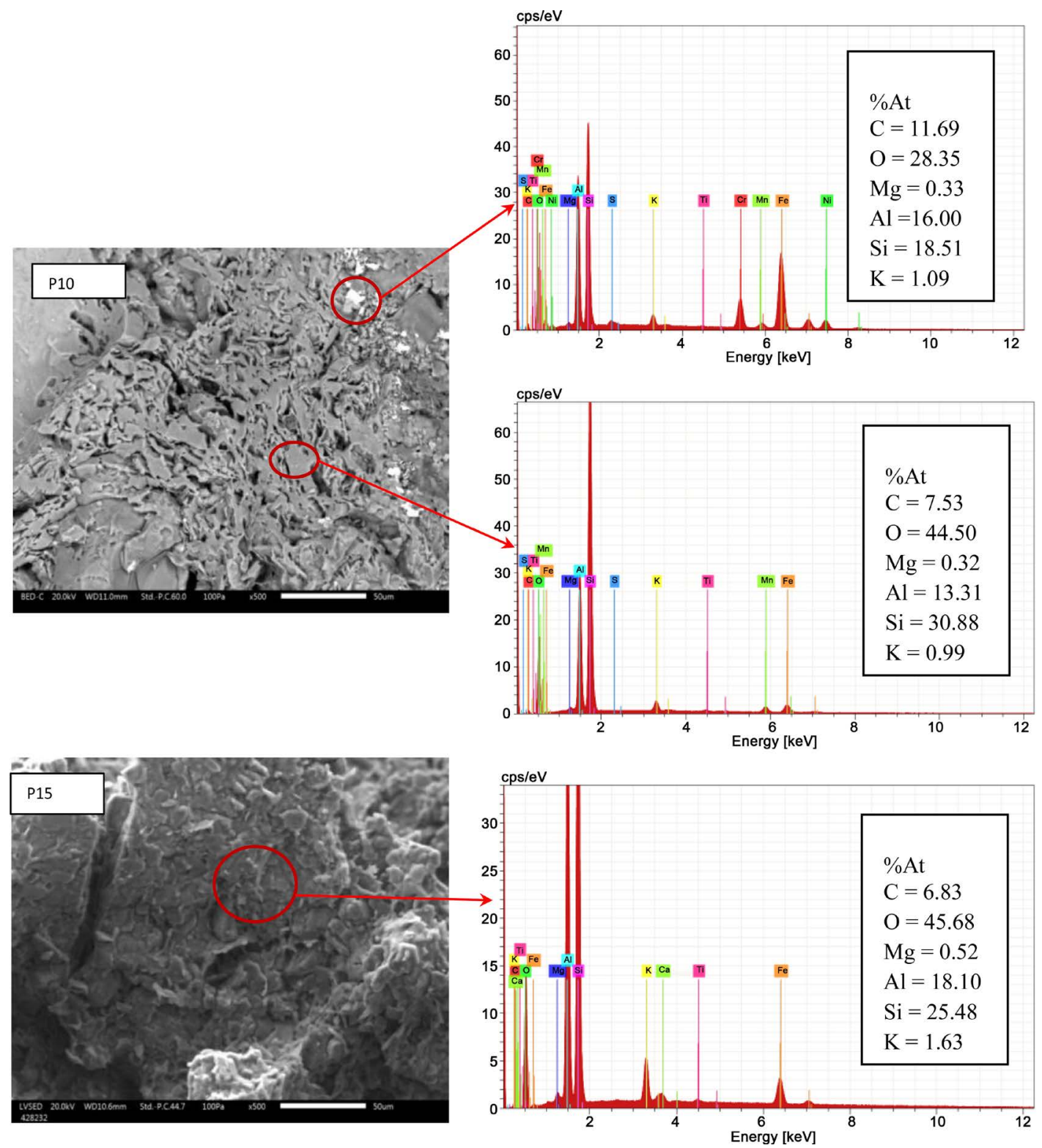

Figure 9. SEM image of fractured surface of $\mathrm{P} 10$ and $\mathrm{P} 15$ at $1300^{\circ} \mathrm{C}$. 
empilement of particles without densification. The chemical evolution shows the reduction of $\mathrm{SiO}_{2}$ with $\mathrm{RHS}$ increasing and the increase of $\mathrm{Al}_{2} \mathrm{O}_{3}$ with RHS increasing.

For all the pots, during the sintering, iron oxides are accumulated and seem not participated on the formation of new phases like mullite. But, with the increase of temperature, the iron oxides can help the fluxing action of $\mathrm{K}_{2} \mathrm{O}$ on the formation of liquid phase.

\section{Conclusion}

Porous pots have been elaborated with raw clay and rice husks from Burkina Faso. The mechanical, mineralogical and microstructural properties of elaborated pots change with sintering temperature and rice husks quantity. The sintering temperature increasing promotes the densification of pots and reduces then its porosity due to the formation of liquid phase by fluxing action. The mechanical properties are enhancing with temperature linked to the formation of liquid and mullite phase whose quantities increase with temperature. With rice husks, the densification is reduced and the porosity increases. However the pots with $10 \% \mathrm{wt}$ of rice husks and sintering at $1300^{\circ} \mathrm{C}$ during 30 minutes present an interesting porosity and mechanical strength which enable him to be used in the filtration of water. Up to $10 \%$ wt of rice husks, the porosity is very high but the feeble solidity of pots is not interesting for its use in water filtration.

\section{References}

[1] L'observateur Paalga quotidien d'information Nº 9116 du lundi 16 mai 2016. http://www.lobservateur.bf/ paalga/

[2] ADI, International Inc. (1997) Arsenic in Drinking Water Supplies. Technical Bulletion, 1997-AS-01.

[3] Sancha, A.M., O’Ryan, R. and Perez, O. (1998) The Removal of Arsenic from Drinking Water and Associated Costs: The Chilean Case. Interdisciplinary Perspectives on Drinking Water Risk Assessment and Management. Proceedings of the Santiago Symposium, September 1998.

[4] Bouras, O. (2003) Propriétés adsorbantes d'argiles pontées organophiles: synthèse et caractérisation. Thèse de Doctorat de l'Université de Limoges, Limoges, France.

[5] Ebele E., Isah, B.K. and Tolulope, L.A. (2014) Development of Ceramic Filters for Household Water Treatment in Nigeria. Art and Design Review, 2, 6-10.

https://doi.org/10.4236/adr.2014.21002

[6] Pérez, J.M., Rincon, J.M. and Romero, M. (2012) Effect of Moulding Pressure on Microstructure and Technological Properties of Porcelain Stoneware. Ceramics International, 38, 317-325. https://doi.org/10.1016/j.ceramint.2011.07.009

[7] AFNOR (Association Française de Normalisation) (1993) Norme NF P 94-051 (Sols reconnaissance et essais, Détermination des limites d'Atterberg, Limite de liquidité à lacoupelle, Limite de plasticité au rouleau).

[8] AFNOR (Association Française de Normalisation) (1997) NF EN ISO 10545-3: Carreaux et dalles céramiques. Partie 3: Détermination de l'absorption d'eau, de la porosité ouverte, de la densité relative apparente et de la masse volumique globale (remplace l'EN 99), 1-3. 
[9] AFNOR (Association Française de Normalisation) (1997) NF EN ISO 10545-4: Carreaux et dalles céramiques. Partie 4: Détermination de la résistance à la flexion et de la force de rupture (remplace l'EN 100 et la NBN B 27-008), 1-4.

[10] Casagrande, A. (1932) Research on Atterberg Limits of Soils. Public Roads, 13, 121-136.

[11] Seynou, M., Flament, P., Sawadogo, M., Tirlocq, J. and Ouedraogo, R. (2013) Refractory Bricks Based on Tikaré (Burkina Faso) Kaolinitic Raw Clay Material. Journal de la Société Ouest Africaine de Chimie, 35, 49-56.

[12] Zerbo, L. (2009) Transformations thermiques et réorganisation structurale d'une argile du Burkina Faso. Thèse de l'Université de Ouagadougou, Ouagadougou, Burkina Faso.

[13] Yvon, J., Garin, P., Delon, J.F. and Cases, J.M. (1982) Valorisation des argiles kaoliniques des Charentes dans le caoutchouc naturel, Bulletin de Minéralogie, 105, 535-541.

[14] Görhan, G. and Simsek, O. (2013) Porous Clay Bricks Manufactured with Rice Husks. Construction and Building Materials, 40, 390-396.

https://doi.org/10.1016/j.conbuildmat.2012.09.110

[15] Seynou, M. (2009) Caractérisation de matières premières argileuses des sites de Loulouka et de Korona (Burkina Faso): Valorisation dans la céramique du carreau. Thèse de l'Université de Ouagadougou, Ouagadougou, Burkina Faso. 